\title{
International relations of Russia from the perspective of educational migration
}

\section{Relaciones internacionales de Rusia desde la perspectiva de la migración educativa}

\author{
KARIMOVA, Luiza†'*, SAGITOVA, Victoria"', KIRPICHNIKOVA, Anna"' and HOANG, Ha"', \\ 'Candidate of Historical Sciences, Associate Professor, Department of Regional Studies and Eurasian Studies, Institute of \\ International Relations, Kazan Federal University, Russia. \\ "Candidate of psychological Sciences, Associate Professor, Department of Altaic studies and Chinese studies, Institute of \\ International relations, Kazan Federal University, Russia. \\ "'PhD in Philology, senior lecturer, Department of Foreign Languages, Institute of International Relations, Kazan Federal \\ University, Russia. \\ "'PhD, Faculty of Psychology and Education, The University of Danang - University of Science and Education, Danang, \\ Vietnam.
}

ID $1^{\text {st }}$ Author: Luiza, Karimova / ORC ID: 0000-0002-0353-8493, ID Scopus: 56684902700

ID $1^{\text {st }}$ Co-author: Victoria, Sagitova / ORC ID: 0000-0001-7002-4719, ID Scopus: 57211500425

ID $2^{\text {nd }}$ Co-author: Anna, Kirpichnikova / ORC ID: 0000-0003-4261-8004, ID Scopus: 57201644544

ID $3^{\text {rd }}$ Co-author: Ha, Hoang / ORC ID: 0000-0002-2964-5879

DOI: $10.35429 /$ EJM.2021.27.12.16.22

Received July 20, 2021; Accepted December 30, 2021

\begin{abstract}
Educational migration being a part of social and intellectual migration is one of the most serious factors of the development of countries taking part in this process. Perspectivity and relevance of studying the dynamics of international relations of the Russian Federation from the perspective of educational migration are determined by opportunities to analyze the dynamics of the social structure of the society and mobility of different groups and communities under the influence of migration. The article using general scientific methods (analysis, synthesis, comparison, classification, etc.) and methods of applied statistics consider (on the basis of official statistical data) the dynamics of the group of foreign students and graduates studied in Russian institutions of higher education, their distribution across the country, trying to find out the regions for which Russian education is more attractive. Authors draw conclusions that for foreign students Russian Federation is getting more attractive that is proven by the increase in their amount from the early 2000-s.
\end{abstract}

International processes, Educational migration, Russian Federation, International migration

\begin{abstract}
Resumen
La migración educativa como parte de la migración social e intelectual es uno de los factores más graves para el desarrollo de los países que participan en este proceso. La perspectiva y la relevancia del estudio de la dinámica de las relaciones internacionales de la Federación de Rusia desde la perspectiva de la migración educativa están determinadas por las oportunidades para analizar la dinámica de la estructura social de la sociedad y la movilidad de diferentes grupos y comunidades bajo la influencia de la migración. El artículo que utiliza métodos científicos generales (análisis, síntesis, comparación, clasificación, etc.) y métodos de estadística aplicada considera (sobre la base de datos estadísticos oficiales) la dinámica del grupo de estudiantes y graduados extranjeros estudiados en instituciones rusas de educación superior., su distribución en todo el país, tratando de descubrir las regiones para las que la educación rusa es más atractiva. Los autores llegan a la conclusión de que para los estudiantes extranjeros la Federación de Rusia se está volviendo más atractiva, como lo demuestra el aumento de su cantidad desde principios de los 2000 .
\end{abstract}

Procesos internacionales, Migración educativa, Federación de Rusia, Migración internacional

Citation: KARIMOVA, Luiza, SAGITOVA, Victoria, KIRPICHNIKOVA, Anna and HOANG, Ha. International relations of Russia from the perspective of educational migration. ECORFAN Journal-Mexico. 2021. 12-27:16-22.

\footnotetext{
* Correspondence to Author (E-mail: LU_KA_S@rambler.ru)

$\dagger$ Researcher contributing first author.
} 


\section{Introduction}

The relevance of the topic is determined by the processes occurring in many countries, such as overcrowding, "demographic pitfalls." (Kea, 2020). One of the solutions to the problems is educational migration, which allows increasing the amount of able-bodied population and proportion of highly professional specialists in the labor market that promotes the development of business industry in the sphere of support of academic activities (Holmes, 2006; Qiu, 2020).

The perspective of studying the dynamics of different countries' international relations, in particular Russia, by means of educational migration is determined by the opportunities to analyze the dynamics of the social structure of the society and mobility of different groups and communities under the influence of migration. According to some data, educational migration can be considered as an integral part of social migration (Grunin et al., 2015). According to another one, it can be included in intellectual migration (Ivakhnyuk, 2006; Alekseeva, 2012; Belov, 2020).

Educational migration can be considered from different points of view:

1. As "a part of social migration whose object is the social interaction of individuals involved in social and geographical moving in order to get education and subject is dynamics of changes in objective and subjective aspects of individuals' social relations within previous and new society" (Samofalova, 2020).

2. As "migration aiming to get or continue education (educational and study migration are synonyms in this case)" (Zamotin, 2016; Aucejo, 2021).

3. As "soft power" of impact on other countries, their population and politics without the military and heavy-handed methods.
Educational migration contains student migration (getting the education and raising the level of qualification), different internships, additional education, courses, and other forms, which allow increasing the level of qualification (moving of pupils, students at secondary specialized colleges and institutions of higher education, PhD. students, doctorate students, interns, specialists, increasing the level of qualification in different educational institutions, departments, and companies).

Metelev (2016) distinguishes two types of moving in the structure of educational migration:

1. Relocation.

2. Scientific and educational migration (migration of students and interns between countries in order to obtain new skills and to be included in international labor nets, research nets, and communicative relations) (Metelev, 2016).

Effects of educational migration can be different such as social, political, demographical, and economic. Among the advantages there are:

1. High level of migrant's mobility and tolerance owing to age characteristics.

2. Opportunity to have an impact on the reproductive intensions of a recipient country.

3. Spending money on household needs while living.

4. Due to study graduates with the necessary set of skills and competences enters the labor market.

5. The process of migrant's adaptation competence in the language of the recipient country; understanding other country's customs and stereotypes.

6. If the student stays in the country after graduation, he/she sides with the economics of the country. If he/she goes back, he becomes an influence agent in the territory of his / her own country (Study migration from the CIS and Baltic countries: potential and prospects for Russia, 2012). 
Among the disadvantages of educational migration, there are:

1. Foreigners fill state-financed openings.

2. There are additional strains on social systems and utility infrastructures.

3. Expenses on migrant's adaptation and integration.

4. Expenses on recruiting abroad and branding of the institute's program.

5. Risk of decrease in quality of student groups' work because of foreigners.

6. Low initial level of students recruited leads to a decrease in knowledge level and devaluation of study, consequently, to the formation of non-professional graduates and specialists.

It is proven by the results of the research (2007-2008) of foreign students and Ph.D. students who studied in Russia (Moscow, Stavropol, Ivanovo, Belgorod, Voronezh, and Novosibirsk) (Zamotin, 2016; Volokh \& Grishaeva, 2017; Iakovleva, et al., 2021).

\section{Methods}

As mentioned earlier, in this paper, it was aimed to investigate the international relations of Russia from the perspective of educational migration. because of educational migration being a part of social and intellectual migration is one of the most serious factors of the development of countries taking part in this process. Perspectivity and relevance of studying the dynamics of international relations of the Russian Federation from the perspective of educational migration are determined by opportunities to analyze the dynamics of the social structure of the society and mobility of different groups and communities under the influence of migration. The article using general scientific methods (analysis, synthesis, comparison, classification, etc.) and methods of applied statistics consider (on the basis of official statistical data) the dynamics of the group of foreign students and graduates studied in Russian institutions of higher education, their distribution across the country, trying to find out the regions for which Russian education is more attractive.
The study uses general scientific theoretical methods such as analysis, synthesis, comparison, classification, etc., and special methods such as methods of applied statistics as well.

The method of classification allows dividing studied social categories of educational migrants into well-organized and classified groups on the basis of different factors (nationality, level of education, etc.). Owing to applied statistics methods it was possible to count the number of people included in each category, their proportion, and dynamics.

\section{Results and Discussion}

Migration is still a highly topical issue for Russian scientists (Ilikova \& Venidiktova, 2019) and for foreigners as well (Sakaev, 2018). Particular attention is given to processes of migration in general (global migration processes, cultural chasms, risks related to migration processes, etc.) and different aspects of educational migration as well ("brain drain," internationalization of higher education, integration of migrants via educational institutions, adaptation of foreign students, etc.)

Analyzing statistical data available to the public, one can notice some tendencies, which allow forecasting and drawing conclusions about the quality of international educational migration, increase in the proportion of foreign students in Russian higher education institutions, development of international relations of Russian Federation with certain countries.

The national tendency of demographical changes is rising year-by-year (tab. 1). An increase in the population at the age of $11-17$ (18) allows the understanding of how possible migration moving is and the dynamics of these processes.

\begin{tabular}{|c|c|c|c|c|c|}
\hline \multirow[t]{2}{*}{ Country } & \multicolumn{5}{|c|}{$\begin{array}{l}\text { The number of students in general } \\
\text { academic schools on a country-by- } \\
\text { country basis (millions of people) }\end{array}$} \\
\hline & 2012 & 2014 & 2015 & 2016 & 2017 \\
\hline Russia & 20,8 & 6,2 & 6,4 & 6,7 & 7,0 \\
\hline $\begin{array}{l}\text { Great } \\
\text { Britain }\end{array}$ & 31,5 & 4,6 & 4,5 & 4,6 & 4,7 \\
\hline Germany & 18,0 & 2,9 & 2,9 & 2,9 & 2,9 \\
\hline Italy & 25,7 & 2,9 & 2,9 & 2,9 & 2,8 \\
\hline Canada & 31,3 & 2,2 & 2,2 & 2,3 & 2,3 \\
\hline USA & 30,9 & 24,4 & 24,5 & 24,8 & 25,0 \\
\hline Sweden & 28,7 & 0,7 & 0,8 & 0,8 & 0,8 \\
\hline Japan & 32,8 & 6,8 & 6,7 & 6,6 & 6,6 \\
\hline
\end{tabular}

Table 1 Quantitative indicators of the dynamics of students in general academic schools on a country-by-country basis Source: (Shakirova, 2019)

KARIMOVA, Luiza, SAGITOVA, Victoria KIRPICHNIKOVA, Anna and HOANG, Ha. International relations of Russia from the perspective of educational migration. ECORFAN Journal-Mexico. 2021 
According to the Ministry of Education of the Russian Federation, the number of foreign students who were studying at Russian universities on the basis of public education grants or on the contract base was 59.9 thousand people in 1998. After the decrease by $9 \%$ in 2000 (54.5 thousand people), it increased dramatically: in $2002-60.9$ thousand people (Aupetit, 2006), in 2010 - 153.8 thousand people, in 2017 - 260.1 thousand people (Belot \& Ederveen, 2012; Iakovleva, et al., 2021). Data of 2010 and 2017 took into account students who studied in undergraduate, specialist, and graduate programs at universities and research organizations in Russia. Thus, during the last 20 years, the number of foreign students in Russia has increased more than fourfold.

During the period from 1998 to 2002 in Russian universities, there was an increase in the number of students from Baltic countries (from 3 thousand people (5\% of total) to 4.2 thousand people (6.7\% of total)), Asia (from 30.7 thousand people $(51.3 \%$ of total) to 33.4 thousand people (54.8\% of total)), the USA (from 1.6 thousand people $(2.7 \%$ of total) to 2.2 thousand people (3.6\% of total)), Canada (from 0.1 thousand people $(0.2 \%$ of total) to 0.3 thousand people $(0.5 \%$ of total $))$, Africa, excluding Northern Africa (from 4.8 thousand people (8\% of total) to 5.6 thousand people $(9.2 \%$ of total)), Australia and New Zealand (from 0 to 0.3 thousand people $(0.5 \%$ of total $))$. There was no change in the number of students from Latin America (1.6 thousand people (from $2.7 \%$ to $2.6 \%$ )), and there was a decrease in the number of students from Europe (7.2 thousand people (12\%) to 5.5 thousand people $(9 \%)$ ), from the Middle East and Northern Africa (from 11.5 thousand people $(19.2 \%)$ to 7.8 thousand people $(12.8 \%)$ ) (Aupetit, 2006). The most significant increase was in the number of students from Asia.

Over time from 210-2011 academic year to 2017-2018 academic year, the number of foreign students enrolled at universities and graduated from them increased from 37.3 thousand people $(24.3 \%$ of the total amount of foreign students) to 86.0 thousand people (33\%), and the proportion of foreign graduates from Russian universities and scientific organizations decreased from $64.6 \%$ (24.1 thousand people) to $47.7 \%$ (41.1 thousand people) (Belot \& Ederveen, 2012).
It can be explained by many factors: problems of adaptation of foreign students at universities and regions, insufficient proficiency (especially, language proficiency), educational programs are not adaptable enough to be taught to foreign students, students' financial problems, etc.

There was an increase in the amount and proportion of students from European countries: from 1.3 thousand people $(0.8 \%$ of the total amount of foreign students) to 2.7 thousand people ( $1 \%$ of the total amount of foreign students). At the same time while the number of students enrolled at universities and graduates was growing (from 0.3 thousand people to 1.0 thousand people and from 0.3 thousand people to 0.5 thousand people respectively), their proportion decreased dramatically (from $8 \%$ to $1.2 \%$ and from $12.4 \%$ to $1.2 \%$ respectively) (Belot \& Ederveen, 2012; Iakovleva, et al., 2021).

Despite the significant increase in the number of Chinese students in Russian universities and scientific organizations in general, including students who enrolled at universities and graduated from them (from 28.1 thousand people to 47.4 thousand people), their proportion even went down (from $18.3 \%$ to $18.2 \%$ ). However, in 2010-2017 among Asian countries, China was a leader in the total amount of students studying in Russia (enrolled at Russian universities and graduated from them). Then, in 2010, it was followed by India (annual increase), Malaysia (annual decrease), Vietnam, Mongolia, the Syrian Arab Republic, the Republic of Korea, Democratic People's Republic of Korea (Northern Korea) in decreasing order. In 2017, their positions were a little bit different: India, Vietnam, Mongolia, the Syrian Arab Republic, the Republic of Korea, Democratic People's Republic of Korea (Northern Korea) (Belot \& Ederveen, 2012; Aucejo, 2021).

The number of students from Asian countries who enrolled at Russian universities increased from 7.3 thousand people in 2010 to 18.3 thousand people in 2017, and their proportion went up as well - from $19.6 \%$ of the total amount of foreign students to $21.2 \%$ of the total amount of foreign students. The greatest number of Asian students was from China. In 2010, it was followed by Vietnam, India (annual increase), Malaysia (annual decrease), Mongolia, the Syrian Arab Republic, the Republic of Korea, Democratic People's Republic of Korea (Northern Korea) in decreasing order. 
By 2017, the situation had changed: China was followed by India, Vietnam, Mongolia, the Syrian Arab Republic, Malaysia, and the Republic of Korea. In the 2016/2017 academic year among people enrolled at Russian universities. There were no people from the Democratic People's Republic of Korea (Northern Korea), and there were no people from this country who graduated from Russian universities during the period under consideration (Belot \& Ederveen, 2012; Iakovleva, et al., 2021).

The number of graduates from Asian countries increased from 6.8 thousand people to 8.3 thousand people, but their proportion of the total amount of foreign students decreased from $28.2 \%$ to $20.2 \%$. In 2010, China was followed by India, Vietnam, Malaysia, Mongolia, the Syrian Arab Republic, the Republic of Korea in decreasing order. In 2017 - Vietnam, India, Malaysia, Mongolia, the Syrian Arab Republic, the Republic of Korea. Among graduates from Russian universities, there were no people from the Democratic People's Republic of Korea (Northern Korea) during the period under consideration (Belot \& Ederveen, 2012).

The total amount of students from Central and Southern Africa and their proportion in the number of all foreign students decreased from 0.9 thousand people $(0.6 \%)$ to 0.8 thousand people $(0.3 \%)$. At the same time, the number of people enrolled at universities and the number of graduates increased: from 0.2 thousand people to 0.8 thousand people $(0.5 \%$ to $0.9 \%)$ and from 0.1 thousand people to 0.3 thousand people $(0.4 \%$ to $0.7 \%$ ) respectively (Belot \& Ederveen, 2012).

Despite the increase in the amount and proportion of students from Northern America (the USA and Canada) from 0.1 thousand people to 0.2 thousand people (from $0.06 \%$ to $0.07 \%$ ), the number of people from the USA and Canada enrolled at Russian universities stayed at the same level ( 0.1 thousand people) and the proportion in the amount of all foreign students even decreased from $0.3 \%$ to $0.1 \%$. The graduates from these countries were only in 2015 and 2016 (0.1 thousand people a year) (Belot \& Ederveen, 2012).

The total amount of African students increased from 6.7 thousand people $(4.4 \%)$ to 15.0 thousand people $(5.8 \%)$ during the period under consideration.
According to the growth rate, students from Morocco were first in the line, followed by Nigeria, Zambia, Kameron, and Kenya. The number of African people enrolled at Russian universities rose from 1.4 to 5.2 thousand people (from $3.8 \%$ to $6 \%$ ), graduates - from 1.0 to 2.0 thousand people (from 0.4 to $0.5 \%$ ). Among foreigners from African countries who won admission to Russian universities, students from Morocco and Nigeria were first with the same amount of people enrolled at universities, followed by Zambia and Kameron. By 2017, people from Morocco were first, leading by a significant margin and followed by Nigeria, Kameron, and Zambia. Among graduates in 2010, leading positions were taken by Morocco, Nigeria, Zambia, in 2017 - Nigeria, Morocco, Zambia, Kenya (Belot \& Ederveen, 2012; Aucejo, 2021).

\section{Summary}

Migration processes create new educational needs of recipient country at the international level, and at the same time, the choice of a country for educational migration is related to increasing the prestige of the donor-country and giving more opportunities to educational migrant in the country of living and in the country of studying as well. At the level of the state, it solves social, political problems and economical as well.

The Russian Federation is getting more and more attractive for foreign students that are proven by positive dynamics of their amount from the early 2000-s.

During the period from 2010 to 2017 , owing to educational migration, Russia strengthened international relations with European countries, the USA and Canada, countries of Central and Southern America, although the proportion of the representatives from these countries decreased that happened because of more intensive educational migration processes from Asian and African countries.

\section{Conclusions}

Assessing migration processes within the framework of international educational migration, one can say that prestige of education in the Russian Federation is gradually increasing for countries of Africa and Asia region, and that is determined by state policy connected with these countries as well as opportunities to study culture and language of the countries comprising this region in order to improve international relations. 
During the last decade owing to educational migration, the international relations of Russia with European countries, the USA and Canada, Central and South America are growing strong, although the general number of the students from these countries dropped because of the intensive processes of educational migration from Asian and African countries.

\section{Acknowledgements}

The work is performed according to the Russian Government Program of Competitive Growth of Kazan Federal University.

\section{References}

Alekseeva, E.N. (2012). Features and prospects of educational migration in the era of global transformations. Proceedings of Moscow University. Sociology and political science, 4(18), 113-136.

Aucejo, E. A. (2021). Migración internacional, economía productiva y educación superior en el marco de la Agenda 2030 de Naciones Unidas. Revista de Educación y Derecho, (23)

Aupetit, S. D. (2006). The brain drain in Mexico - a subject for research... or agenda? Globalisation, Societies and Education, 4(1), 103120.

Belot, M., \& Ederveen, S. (2012). Cultural barriers in migration between OECD countries. Journal of Population Economics, 25(3), 10771105.

Belov, F. D. (2020). Educational migration: factors influencing the attraction of foreign young scientists and the return of Russian young scientists. RUDN Journal of Economics, 28(1), 184-195.

Collins, J. (2012). Migration, sociolinguistic scale, and educational reproduction. Anthropology \& Education Quarterly, 43(2), 192213.

Grunin, A. A., Ermakov, D. N., Andriuschenko, G. I., Leskova, I. V., \& Mozdokova, U. S. (2015). International cooperation of Russia and members of commonwealth of independent states (cis) in the area of social security. Biosciences Biotechnology Research Asia, 12(1), 903-907.
Holmes, R. (2006). The THES university rankings: are they really world class?. Asian Journal of University Education (AJUE), 2(1), 1-14.

Iakovleva, S., Cherkashina, T., \& Novikova, N. (2021). La influencia del mundo virtual en el raciocinio de los estudiantes en el contexto de la cultura prefigurativa y la perspectiva de la creación de nuevas tecnologías educativas. La Colmena, 77 90.

Ilikova, L. E., \& Venidiktova, E. A. (2019). Global Migration Challenges, International Organizations and European Politics. Academic Journal of Interdisciplinary Studies, 8(4), 170-170.

Ivakhnyuk, I. (2006, June). Migration in the CIS region: common problems and mutual benefits. In International Symposium on International Migration and Development, Population Division. UN DESA, Turin.

Kea, P. (2020). Gambian educational migration, care and the persistence of the domestic moral economy. Children's Geographies, 18(6), 642-653.

Metelev, S. E. (2016). Migration as a threat to national security. Indian Journal of Science and Technology, 9(14), 1-6.

Qiu, S. (2020). Chinese 'Study Mothers' in Living Apart Together (LAT) Relationships: Educational Migration, Family Practices, and Gender Roles. Sociological Research Online, 25(3), 405-420.

Sakaev, V. (2018). Risks of the high-scale immigration in the public discourse of Russia. Revista San Gregorio, (23), 92-99.

Samofalova, E. I. (2020). Educational migration: a problem field and basic characteristics. SciPeople Science Network. URL: http://scipeople.ru/publication/69692/ (date of access: 16.05.2020).

Schneeweis, N. (2008). Education institutions and integration of migrants. Journal of Population Economics, 24, 1281-1308.

Shakirova, A. (2019). Internationalization of Higher Pedagogical Education. ARPHA Proceedings, 1, 613.

Volokh, V.A., \& Grishaeva, S.A. (2017). International educational migration in modern Russia: features, problems and prospects. Social policy and sociology, 16(1), 80-87.

KARIMOVA, Luiza, SAGITOVA, Victoria, KIRPICHNIKOVA, Anna and HOANG, Ha. International relations of Russia from the perspective of educational migration. ECORFAN Journal-Mexico. 2021 
Vykhovanets, O.D. (2007). Management of migration processes. Migration and development. M, P. 31. 2007.

Zamotin, M. P. (2016). Educational migration in migratory research of Russian authors.

Zhou, Y., Jindal-Snape, D., Topping, K., \& Todman, J. (2008). Theoretical models of culture shock and adaptation in international students in higher education. Studies in higher education, 33(1), 63-75). 